\title{
Evaluation of different plant oils against Lasioderma serricorne Fab. on fennel
}

\author{
Krishna Rolania* and M. C. Bhargawa ${ }^{1}$ \\ *Department of Entomology, College of Agriculture, Choudhary Charan Singh Haryana Agriculture University, \\ Hisar, INDIA \\ ${ }^{1}$ Department of Entomology, Shree Karan Narendra Agricultural University, Jobner, Jaipur (Rajasthan), INDIA \\ *Corresponding author. E-mail: krish81rolania@rediffmail.com
}

Received: September 1, 2014; Revised received: January 15, 2015; Accepted: March 2, 2015

\begin{abstract}
A laboratory experiment was conducted during 2007-2008 at SKN Agricultural University, Jobner on evaluation of different plant oils viz., neem, karanj, mustard, groundnut, lemongrass and citronella oils ( $0.1,0.5$ and $1.0 \mathrm{ml} / 100 \mathrm{~g}$ seeds) and one chemical, malathion ( $0.025,0.050$ and 0.075 per cent) against Lasioderma serricorne on fennel seeds. The malathion at all concentrations was found to be most lethal, causing cent per cent mortality of adults. Neem oil was found to be most effective in increasing the developmental period (78.23 days) and reducing adult emergence (19.02 per cent), longevity of adult (male: 11.1 days and female: 12.0 days), seed damage (5.10 per cent), weight loss (2.60 per cent) followed by karanj and lemongrass oils at $1.0 \mathrm{ml} / 100 \mathrm{~g}$.
\end{abstract}

Keywords: Cigarette beetle, Fennel, Karanj, Lasioderma serricorne, Neem, Oils

\section{INTRODUCTION}

The cigarette beetle, L. serricorne. (Coleoptera: Anobiidae) is a serious pest of several stored commodities. Beside its main host tobacco and cigarettes, it has also been recorded on turmeric, ginger, castor beans, wheat, coconut meal, pepper, cardamom, mustard, chilli, fennel, cumin and opium leaves (Dimetry et al., 2004; Sharma, 2007; Mahroof and Phillips, 2008). The plants, having insecticidal and other activities gained attention in last few decades. Plant products are known to have many advantages, as they are safe to environment and consumer. Inability of the insect pest to develop resistance against them is added advantage. One of the eco-friendly and economic approaches, to keep the stored food grains free from insect attack, would be using the plant products as grain protectants. The growing awareness of environmental hazards due to synthetic insecticides has attracted attention towards pesticides of plant origin. There are encouraging reports on the use of certain indigenous plant products as grain protectants (Jacob and Sheila, 1990; and Bhargava and Meena, 2002). Therefore, in the present studies, some plant oils have been evaluated to find out their effectiveness against this pest under laboratory conditions.

\section{MATERIALS AND METHODS}

The fennel seeds were sterilized at $60 \pm 5^{0} \mathrm{C}$ for 8 hours in order to eliminate both apparent and hidden infestation of insects and mites, if any. These grains were conditioned at least for a week in an environmental chamber maintained at $30 \pm 2^{0} \mathrm{C}$ and 75 per cent relative humidity to raise their moisture content. Stock solution of different plant oils was prepared in acetone (GR grade). $10 \mathrm{ml}$ solution of $1.0,5.0$ and 10.0 per cent concentration of test oils were mixed with $100 \mathrm{~g}$ seeds in such way to get a uniform coating which would give the doses of $0.1,0.5$ and $1.0 \mathrm{ml} / 100 \mathrm{~g}$ seeds. Aliquot of malathion was diluted to $0.025,0.05$ and 0.075 per cent solution for treating the seeds. Ten pairs of newly emerged adults were released in jar containing treated seeds with different plant oils for taking the observations on developmental period, adult emergence, adult longevity, abnormalities if any, seed damage and weight loss. Control seeds were treated with acetone only. There were three replications for each treatment. Development period was work out by recording the dates of egg lying and dates of adult emergence on treated food with different doses of test oils. The per cent adult emergence was worked out on the basis of number of eggs laid and number of adults emerged. The longevity of adults was determined by recording the dates of their emergence and the dates of their natural death. The per cent seed damage and weight loss was calculated as per the procedure given by Adams and Schulten (1978) and Haris and Lindblad (1981). Seed damage was calculated by counting the damaged and undamaged seeds. The loss in weight was worked out by subtracting the final weight from the initial weight and converted into \% weight loss. The details of plant oils used in the experiment are given in Table 1. 
Table 1. Details of plant oils used in the study.

\begin{tabular}{cllc}
\hline S.N. & Common name & Botanical Name & Conc./ doses (ml/ 100g of seeds) \\
\hline 1. & Neem oil & Azadirachta indica A. Juss & $0.1,0.5,1.0$ \\
2. & Karanj oil & Pongamia glabra Vent. & $0.1,0.5,1.0$ \\
3. & Mustard oil & Brassica juncea L. & $0.1,0.5,1.0$ \\
4. & Groundnut oil & Arachis hypogaea L. & $0.1,0.5,1.0$ \\
5. & Lemongrass oil & Cymbopogan flexuosus L. & $0.1,0.5,1.0$ \\
6. & Citronella oil & Cymbopogan winterianus & $0.1,0.5,1.0$ \\
\hline
\end{tabular}

\section{RESULTS AND DISCUSSION}

All the dose levels were found significantly superior in increasing the developmental period over control (Table 2). The developmental period increased with the increase in dose level of each treatment. The mean developmental period in different treatments varied from 48.62 to 74.12 days, while in control it was 44.00 days. The neem oil was found to be most effective in increasing the developmental period which was followed by karanj, lemongrass, mustard, citronella and groundnut oil. Not much work on the effect of plant

Table 2. Effect of plant oils on total developmental period of $L$. serricorne.

\begin{tabular}{|c|c|c|c|c|c|c|c|}
\hline \multirow{3}{*}{$\begin{array}{l}\text { Dose } \\
(\mathrm{ml} / 100 \\
\text { g seeds) }\end{array}$} & \multicolumn{7}{|c|}{ Total developmental period (days)* } \\
\hline & \multicolumn{7}{|c|}{$\begin{array}{l}\text { Plant oils } \\
\end{array}$} \\
\hline & Neem oil & Karanj oil & Mustard oil & Groundnut oil & Lemongrass oil & Citronella oil & Mean \\
\hline 0.1 & 70.02 & 69.33 & 51.57 & 46.76 & 60.0 & 47.21 & 57.48 \\
\hline 0.5 & 74.13 & 71.0 & 53.69 & 48.50 & 63.72 & 49.33 & 60.06 \\
\hline 1.0 & 78.23 & 74.25 & 59.74 & 50.60 & 66.32 & 51.13 & 63.38 \\
\hline Mean & 74.12 & 71.52 & 55.0 & 48.62 & 63.34 & 49.22 & \\
\hline \multirow[t]{2}{*}{ Control } & 44.0 & & & & & & \\
\hline & & S.Em \pm & CD at $5 \%$ & C.V. \% & & & \\
\hline \multicolumn{2}{|c|}{ Treatment } & 0.72 & 2.07 & - & & & \\
\hline \multicolumn{2}{|c|}{ Dose } & 0.51 & 1.46 & 3.59 & & & \\
\hline \multicolumn{2}{|c|}{ Treatment $x$ Dose } & 1.25 & 3.58 & - & & & \\
\hline
\end{tabular}

${ }^{*}$ Data based on three replications

Table 3. Effect of plant oils on adult emergence of L. serricorne.

\begin{tabular}{|c|c|c|c|c|c|c|c|c|c|}
\hline \multirow{3}{*}{$\begin{array}{l}\text { Dose } \\
(\mathrm{ml} / 100 \\
\text { g seeds) }\end{array}$} & \multicolumn{9}{|c|}{ Adult emergence (\%)* } \\
\hline & \multicolumn{9}{|c|}{ Plant oils } \\
\hline & Neem oil & Karanj oil & Mustard oil & $\begin{array}{l}\text { Groundnut } \\
\text { oil }\end{array}$ & $\begin{array}{l}\text { Lemongrass } \\
\text { oil }\end{array}$ & \multicolumn{2}{|c|}{ Citronella oil } & \multicolumn{2}{|c|}{ Mean } \\
\hline 0.1 & $32.66(34.85)$ & $35.02(36.28)$ & $42.29(40.56)$ & $57.67(49.41)$ & $39.95(39.20)$ & \multicolumn{2}{|c|}{$50.00(45.00)$} & \multicolumn{2}{|c|}{$42.93(40.88)^{* *}$} \\
\hline 0.5 & $25.23(30.15)$ & $27.17(31.41)$ & $34.97(36.24)$ & $51.23(45.71)$ & $32.26(34.60)$ & \multicolumn{2}{|c|}{$47.92(43.81)$} & \multicolumn{2}{|c|}{$36.46(36.99)$} \\
\hline 1.0 & $19.02(25.84)$ & $22.73(28.46)$ & $30.96(33.81)$ & $43.17(41.07)$ & $26.78(31.16)$ & \multicolumn{2}{|c|}{$44.45(41.81)$} & \multicolumn{2}{|c|}{$31.19(33.69)$} \\
\hline Mean & $25.63(30.42)$ & $28.30(32.14)$ & $36.07(36.91)$ & $50.69(45.40)$ & $32.99(35.06)$ & \multicolumn{2}{|c|}{$47.45(43.54)$} & & \\
\hline \multirow[t]{2}{*}{ Control } & $70.15(56.88)$ & & & & & & & & \\
\hline & & S.Em \pm & CD at $5 \%$ & \multicolumn{6}{|l|}{ C.V. \% } \\
\hline \multicolumn{2}{|c|}{ Treatment } & 0.38 & 1.08 & - & & & & & \\
\hline \multirow{2}{*}{\multicolumn{2}{|c|}{$\begin{array}{l}\text { Dose } \\
\text { Treatment x Dose }\end{array}$}} & 0.27 & 0.76 & \multicolumn{6}{|l|}{3.03} \\
\hline & & 0.65 & 1.87 & - & & & & & \\
\hline \multicolumn{10}{|c|}{ "Data based on three replications; "* Percentages transformed to angles; outside values are its back transformation to percentages } \\
\hline \multirow{3}{*}{$\begin{array}{l}\text { Dose } \\
(\mathrm{ml} / 100 \mathrm{~g} \\
\text { seeds) }\end{array}$} & \multicolumn{9}{|c|}{ Longevity of male adult (days)* } \\
\hline & \multicolumn{9}{|c|}{ Plant oils } \\
\hline & Neem oil & Karanj oil & Mustard oil & Groundnut oil & \multicolumn{2}{|c|}{ Lemongrass oil } & \multicolumn{2}{|c|}{ Citronella oil } & Mean \\
\hline 0.1 & 14.0 & 18.1 & 22.8 & 27.0 & 20.9 & & 25.7 & & 21.4 \\
\hline 0.5 & 12.7 & 15.3 & 20.9 & 25.2 & 17.8 & & 23.3 & & 19.2 \\
\hline 1.0 & 11.1 & 13.7 & 19.9 & 24.0 & 15.6 & & 21.2 & & 17.6 \\
\hline Mean & 12.6 & 15.7 & 21.2 & 25.4 & 18.1 & & 23.4 & & \\
\hline \multirow[t]{2}{*}{ Control } & 38.2 & & & & & & & & \\
\hline & & S.Em \pm & CD at $5 \%$ & \multicolumn{6}{|l|}{ C.V. $\%$} \\
\hline \multicolumn{2}{|c|}{ Treatment } & 0.65 & 1.86 & \\
\hline \multicolumn{2}{|c|}{ Dose } & 0.46 & 1.31 & \multicolumn{6}{|l|}{10.00} \\
\hline \multicolumn{2}{|c|}{ Treatment x Dose } & 1.12 & 3.21 & \multicolumn{6}{|l|}{-} \\
\hline
\end{tabular}

* Data based on three replications 
Table 5. Effect of plant oils on longevity of female adult of L. serricorne.

\begin{tabular}{|c|c|c|c|c|c|c|c|}
\hline \multirow{3}{*}{$\begin{array}{l}\text { Dose } \\
(\mathrm{ml} / 100 \mathrm{~g} \\
\text { seeds) }\end{array}$} & \multicolumn{7}{|c|}{ Longevity of female adult (days)* } \\
\hline & \multicolumn{7}{|c|}{ Plant oils } \\
\hline & Neem oil & Karanj oil & Mustard oil & Groundnut oil & Lemongrass oil & Citronella oil & Mean \\
\hline 0.1 & 15.0 & 19.3 & 23.6 & 28.2 & 21.6 & 26.1 & 22.3 \\
\hline 0.5 & 13.2 & 16.2 & 21.5 & 26.2 & 18.2 & 24.0 & 19.9 \\
\hline 1.0 & 12.0 & 14.6 & 20.6 & 25.1 & 16.3 & 22.5 & 18.5 \\
\hline Mean & 13.4 & 16.7 & 21.9 & 26.5 & 18.7 & 24.2 & \\
\hline \multirow[t]{2}{*}{ Control } & 39.70 & & & & & & \\
\hline & & S.Em \pm & CD at $5 \%$ & C.V. \% & & & \\
\hline \multicolumn{2}{|l|}{ Treatment } & 0.55 & 1.57 & - & & & \\
\hline \multicolumn{2}{|l|}{ Dose } & 0.39 & 1.11 & 8.12 & & & \\
\hline \multicolumn{2}{|c|}{ Treatment $x$ Dose } & 0.95 & 2.72 & - & & & \\
\hline
\end{tabular}

${ }^{*}$ Data based on three replications

Table 6. Effect of plant oils on grain damage by L. serricorne.

\begin{tabular}{|c|c|c|c|c|c|c|c|}
\hline \multirow{3}{*}{$\begin{array}{l}\text { Dose } \\
(\mathrm{ml} / 100 \\
\text { g seeds) }\end{array}$} & \multicolumn{7}{|c|}{ Grain damage (\%)* } \\
\hline & \multicolumn{7}{|c|}{ Plant oils } \\
\hline & Neem oil & Karanj oil & Mustard oil & $\begin{array}{l}\text { Groundnut } \\
\text { oil }\end{array}$ & $\begin{array}{l}\text { Lemongrass } \\
\text { oil }\end{array}$ & Citronella oil & Mean \\
\hline 0.1 & $16.90(24.26)$ & $20.10(26.63)$ & $24.50(29.64)$ & $28.90(32.51)$ & $22.30(28.14)$ & $27.20(31.43)$ & $23.32(28.77)^{* *}$ \\
\hline 0.5 & $4.30(22.20)$ & $17.20(24.49)$ & $23.00(28.65)$ & $24.50(29.66)$ & 17.8024.94) & $22.90(28.58)$ & $19.95(26.42)$ \\
\hline 1.0 & $5.10(13.05)$ & $10.10(21.28)$ & $19.20(25.98)$ & $20.90(27.20)$ & $13.30(21.37)$ & $20.70(27.06)$ & $14.88(22.64)$ \\
\hline Mean & $12.10(19.82)$ & $15.80(24.13)$ & $22.23(28.13)$ & $24.76(29.84)$ & $17.80(24.81)$ & $23.60(29.06)$ & \\
\hline \multirow[t]{2}{*}{ Control } & $40.50(39.52)$ & & & & & & \\
\hline & & S.Em \pm & CD at $5 \%$ & C.V. \% & & & \\
\hline \multicolumn{2}{|c|}{ Treatment } & 0.56 & 1.61 & - & & & \\
\hline \multicolumn{2}{|c|}{ Dose } & 0.40 & 1.14 & 6.47 & & & \\
\hline \multicolumn{2}{|c|}{ Treatment $x$ Dose } & 0.97 & 2.78 & - & & & \\
\hline
\end{tabular}

*Data based on three replications; ${ }^{* *}$ Percentages transformed to angles; outside values are its back transformation to percentages

oils on the development of L. serricorne is available; however, it was correlated with the other insects. The present findings are in accordance with Sharma and Bhargava (2012) who reported maximum developmental period of $L$. serricorne in neem seed kernel extract followed by karanj seed extract, castor oil and eucalyptus oil treated seeds on cumin. Hassan (2001) observed that seed treatment with different plant oils/extracts normally delayed the development of Sitophilus granarius. Similarly, Naik and Dumbre (1984), Singh et al. (1994) and Bhargava and Meena (2002) in Callosobruchus sp., Saxena and Singh (1994) and Singh et al. (1996) in Rizopertha dominica and Jakhar (2004) in Triobolium granarium have also observed to prolong the developmental period by treatment with different plant products. This increase in the developmental period is certainly due to antifeedant action of plant oils, that is why larva fed slowly on treated grains and consequently developmental period was prolonged. The antifeedant response of plant products has also been reported against Callosobruchus chinensis (Girish and Jain, 1974) and R. dominica (Tiwari, 1994).

It is apparent from the data that all the doses of plant oils tested were found to be significantly superior in reducing the adult emergence over control (Table 3 ). The per cent adult emergence gradually decreased with the increase in doses of all the treatments. Regarding different oils, the neem oil was found to be most effective in reducing the adult emergence followed by karanj, lemongrass, mustard, citronella and groundnut oils. The present findings are conformity with Maity (2004) who found significant reduction in adult emergence of L. serricorne by coconut oil, mustard oil and palmolein oil at dosage of $5 \mathrm{ml} / \mathrm{kg}$ seeds. Similarly, Sharma and Bhargava (2012) reported significant reduction in adult emergence of $L$. serricorne when cumin seeds were treated with neem seed extract, karanj seed extract mustard oil, eucalyptus oil and castor oil. The reductions in adult emergence by neem oil have also been reported in $C$. chinensis followed by karanj, cedar and mustard oils (Bhardwaj and Verma, 2012) support the present findings. The reduction in adult emergence with different plant oils may be due to fact that oils influence early development or larval eclosion in addition to adult survival. Hewlett (1947) suggested that mortality caused by oils was due to interference with respiration. The significant difference existed between the doses of plant oils in reducing the longevity of beetles of both sexes (Tables 4 and 5). The longevity gradually decreased with the increase in dose level of the test compounds. The maximum reduction in longevity of adults was observed in neem oil treatment followed by karanj, lemongrass, mustard, citronella and groundnut oils. No work on the effect of plant oils on the 
Table 7. Effect of plant oils on weight loss by L. serricorne.

\begin{tabular}{|c|c|c|c|c|c|c|c|}
\hline \multirow{3}{*}{$\begin{array}{l}\begin{array}{l}\text { Dose } \\
(\mathrm{ml} / 100 \mathrm{~g}\end{array} \\
\text { seeds) }\end{array}$} & \multicolumn{7}{|c|}{ Weight loss (\%)* } \\
\hline & \multicolumn{7}{|c|}{ Plant oils } \\
\hline & Neem oil & Karanj oil & Mustard oil & $\begin{array}{l}\text { Groundnut } \\
\text { oil }\end{array}$ & $\begin{array}{l}\text { Lemongrass } \\
\text { oil }\end{array}$ & $\begin{array}{l}\text { Citronella } \\
\text { oil }\end{array}$ & Mean \\
\hline 0.1 & $5.63(13.69)$ & $6.09(14.18)$ & $10.99(19.32)$ & $13.00(21.12)$ & $8.00(16.40)$ & $11.23(19.59)$ & $9.16(17.62)^{* *}$ \\
\hline 0.5 & $3.78(11.15)$ & $4.36(11.97)$ & $7.52(15.88)$ & $9.33(17.78)$ & $7.95(16.35)$ & $8.19(16.60)$ & $6.86(15.18)$ \\
\hline 1.0 & $2.60(9.21)$ & $3.23(10.25)$ & $4.65(12.42)$ & $7.32(15.67)$ & $5.02(12.88)$ & $5.06(14.02)$ & $4.65(12.41)$ \\
\hline Mean & $4.00(11.35)$ & $4.56(12.13)$ & $7.72(16.13)$ & $9.88(18.19)$ & $6.99(15.21)$ & $8.16(16.60)$ & \\
\hline \multirow[t]{2}{*}{ Control } & $16.00(23.58)$ & & & & & & \\
\hline & & S.Em \pm & CD at 5\% & C.V. \% & & & \\
\hline Treatment & & 0.53 & 1.53 & - & & & \\
\hline Dose & & 0.38 & 1.08 & 11.27 & & & \\
\hline Treatment & $x$ Dose & 0.92 & 2.64 & - & & & \\
\hline
\end{tabular}

*Data based on three replications; **Percentages transformed to angles; outside values are its back transformation to percentage

longevity of L. serricorne is available, however, the same type of work on other insect pests have been discussed. Saxena and Singh (1994) found significant reduction in longevity of adults of $R$. dominica with plant products, support the present findings. Similarly, reduction in longevity of adults has also been reported by the treatment of different plant extracts/oils in $R$. dominica (Yadav, 2001), T. granarium and $S$. granarius (Hassan, 2001) and C. chinensis (Bhargava and Meena, 2002), support the present findings.

All the plant oils used as grain protectants to the cigarette beetle, found to be significantly (9.68-19.70 and 13.70-19.58) more superior in reducing the grain damage and loss in weight in comparison to control (Tables 6 and 7). The efficacy of all plant oils was observed after the end of experiment and mean grain damage and loss in weight ranged from 12.10 to 24.76 and 4.00 to 9.88 per cent, respectively. Maximum reduction in grain damage and weight loss was recorded in neem oil treatment which was followed by karanj oil, lemongrass oil, mustard oil, citronella oil and groundnut oil. Maity (2004) reported significant reduction in weight loss by $L$. serricorne with mustard oil treatments on turmeric, coriander, fennel and black pepper, support the present findings. Similarly, Sharma and Bhargava (2012) also found significant reduction in weight loss by L. serricorne with neem and karanj seed extracts, mustard, caster and eucalyptus oils. Not much work is available on the effect of other plant oils on grain damage and weight loss caused by $L$. serricorne, however, Saxena and Singh (1994) found significant reduction in weight loss by $R$. dominica with castor cake and mustard oil treatments, which support that mustard oil is also helpful to reduce grain damage. The present findings are also supported with the results of Bhardwaj and Verma, (2012) and Kumari et al. (1990), who suggested that different plant and vegetable oils were effective in reducing the grain damage by $C$. chinensis. Thus it may be concluded that the tested plant oils were safer in minimizing the infestation of L. serricorne quite successfully in terms of reduction of grain damage and loss in grain weight.

\section{Conclusion}

The present study revealed that malathion at all concentrations was found to be most lethal, causing cent per cent mortality of adults. Among plant oils neem, karanj, and lemongrass oils at $1.0 \mathrm{ml} / 100 \mathrm{~g}$ seeds were found effective in increasing the developmental period and reducing adult emergence, longevity of adults, seed damage and weight loss. Therefore plant oils may be the best alternate of insecticides because these are safe to environment and human beings.

\section{REFERENCES}

Adams, J. M. and Schulten, G. G. M. (1978). Losses caused by insects, mites and microorganisms. In: Post Harvest Grain Assessment Methods. American Association of Cereal Chemists St. Paul, Minnesota, U.S.A., 193.

Bhardwaj, A. and Verma, S. C. (2012). Vegetable oils as grain protectants against pulse beetle, Callosobruchus chinensis infesting pea seeds. Journal of Insect Science, 25 (3): 241-246.

Bhargava, M.C. and Meena, H.M. (2002). Efficacy of some vegetable oils against the pulse beetle, Callosobruchus chinensis Linn. on cowpea, Vigna unguiculata (L.). Indian Journal of Plant Protection, 30: 46-50.

Dimetry, N. Z.; Barakat, A. A.; El-Metwally, H. E.; Risha, E. M. E.; Abd El Salam, A. M. E. (2004). Assessment of damage and losses in some medicinal plants by the cigarette beetle (Lasioderma serrricorne (F.)). Bulletin of National Research Centre of Egypt, 29: 325-333.

Girish, G. K. and Jain, S. K. (1974). Studies on the efficacy of neem kernel powder against stored grain pests. Bulletin of Grain Technology, $12: 226-228$.

Harris, K. L. and Lindblad, C. J. (1981). Post harvest grain loss assessment methods. American Association of $\mathrm{Ce}$ real Chemists, 12: 193.

Hassan, T.A. (2001). Effect of three plant oils (Sesame, sunflower and castor) against stored grain insects (Trogoderma granarium and Sitophilus granarius). University of Aden Journal of Natural and Applied Sciences, 5 (1) : 103-110.

Hewlett, P.S. (1947). The toxicities of three petroleum oils to the grain weevils. Annals of Applied Biology, 34:575585.

Jacob, S. and Sheila, M. K. (1990). Treatment of green gram seeds with oils against the infestation of the pulse 
beetle, Callosobruchus chinensis L. Plant Protection Bulletin, 42: 9-10.

Jakhar, B.L. (2004). Bio-ecology and management of Khapra beetle, Trogoderma granarium Everts on wheat. Ph.D. (Thesis) submitted to Rajasthan Agricultural University, Bikaner.

Kumari, K.; Sinha, M.M.; Mehta, D.N. and Romoned, S.F. (1990). Effect of some vegetable oils as protectants against Callosobruchus chinensis L. Bulletin of Grain Technology, 28 (1) : 58-60.

Mahroof, R. M.; Phillips, T. W. (2008). Life history parameters of L. S. (F.) as influenced by good sources. Journal of Stored Products Research, 44: 219-226.

Maity, B.K. (2004). Effect of botanicals in protecting stored species against cigarette beetle, Lasioderma serricorne Fab. Journal of Plant Protection and environment, 1 $(1 \& 2)$ : 62-64.

Naik, R.L. and Dumbre, R.B. (1984). Effect of some vegetable oils used in protecting stored cowpea on biology of pulse beetle, Callosobruchus maculatus (Fabr.) (Coleoptera : Bruchidae). Bulletin of Grain Technology, $22: 25-32$.

Saxena, A. and Singh, Y.P. (1994). Effect of some plant products as protectants against Rhizopertha dominica
Fabr. on wheat grains. Bulletin of Grain Technology, $32: 117-121$

Sharma, S.R. (2007). Host preference and management of cigarette beetle, Lasioderma serricorne Fab. on cumin. M.Sc. (Ag.) Thesis Submitted to RAU, Bikaner pp. 69.

Sharma, S. R. and Bhargava, M. C. (2012). Efficacy of some seed protectants against Lasioderma Serricorne (Fabricicus) infesting cumin. Journal of Insect Science, 25 (4): 342-349.

Singh, H.; Mrig, K.K. and Mahla, J.C. (1996). Efficacy of different plant products on the fecundity and emergence of lesser grain borer, Rhizopertha dominica (F.) in wheat grains. Annals of Biology, 12 : 96-98.

Singh, V.N.; Pandey, N.D. and Singh, Y.P. (1994). Effectiveness of vegetable oils on the development of Callosobruchus chinensis Linn. infesting stored gram. Indian Journal of Entomology, 56 : 216-219.

Tiwari, S.N. (1994). Efficacy of some plant products as grain protectants against Rhizopertha dominica (F.) (Coleoptera: Bostrichidae). International Journal of Pest Management, 40 : 94-97.

Yadav, R.P. (2001). Biological effect of some vegetable oils and solar energy on Rhyzopertha dominica (Fab.) on wheat. M.Sc. (Ag.) Thesis submitted to RAU, Bikaner. 